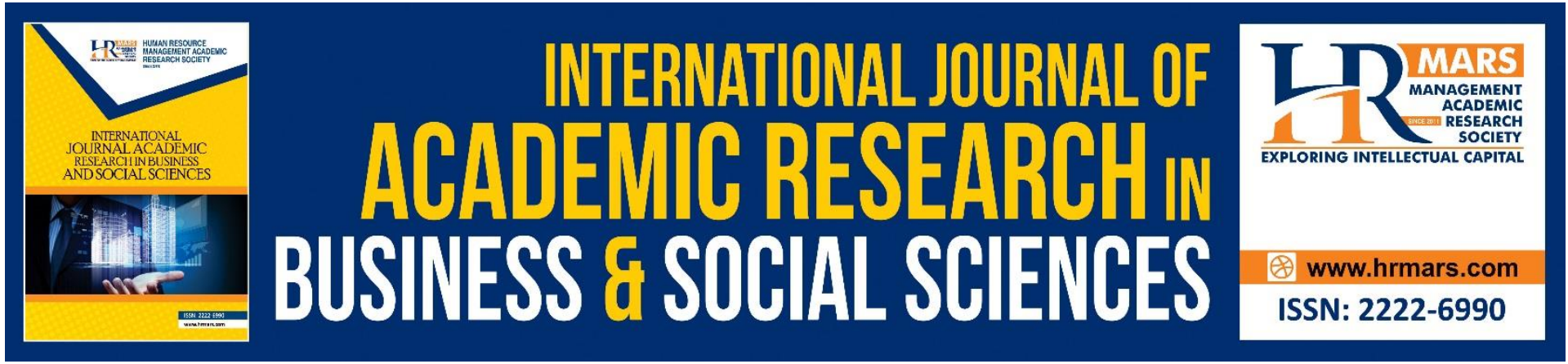

\title{
To Recycle or Not to Recycle: Factors Affecting Recycling Intention among Residents in Semi-Dense Areas in Johor, Malaysia
}

Muhammad Majid, Mohamad Faizal Ramli, Basri Badyalina, Fatin Farazh Ya'acob, Ahmad Faiz Ghazali

To Link this Article: http://dx.doi.org/10.6007/IJARBSS/v11-i8/10560

DOI:10.6007/IJARBSS/v11-i8/10560

Received: 05 June 2021, Revised: 09 July 2021, Accepted: 28 July 2021

Published Online: 07 August 2021

In-Text Citation: (Majid et al., 2021)

To Cite this Article: Majid, M., Ramli, M. F., Badyalina, B., Ya'acob, F. F., \& Ghazali, A. F. (2021). To Recycle or Not to Recycle: Factors Affecting Recycling Intention among Residents in Semi-Dense Areas in Johor, Malaysia. International Journal of Academic Research in Business and Social Sciences, 11(8), 499-519.

Copyright: @ 2021 The Author(s)

Published by Human Resource Management Academic Research Society (www.hrmars.com)

This article is published under the Creative Commons Attribution (CC BY 4.0) license. Anyone may reproduce, distribute, translate and create derivative works of this article (for both commercial and non-commercial purposes), subject to full attribution to the original publication and authors. The full terms of this license may be seen at: http://creativecommons.org/licences/by/4.0/legalcode

Vol. 11, No. 8, 2021, Pg. 499 - 519

Full Terms \& Conditions of access and use can be found at http://hrmars.com/index.php/pages/detail/publication-ethics 


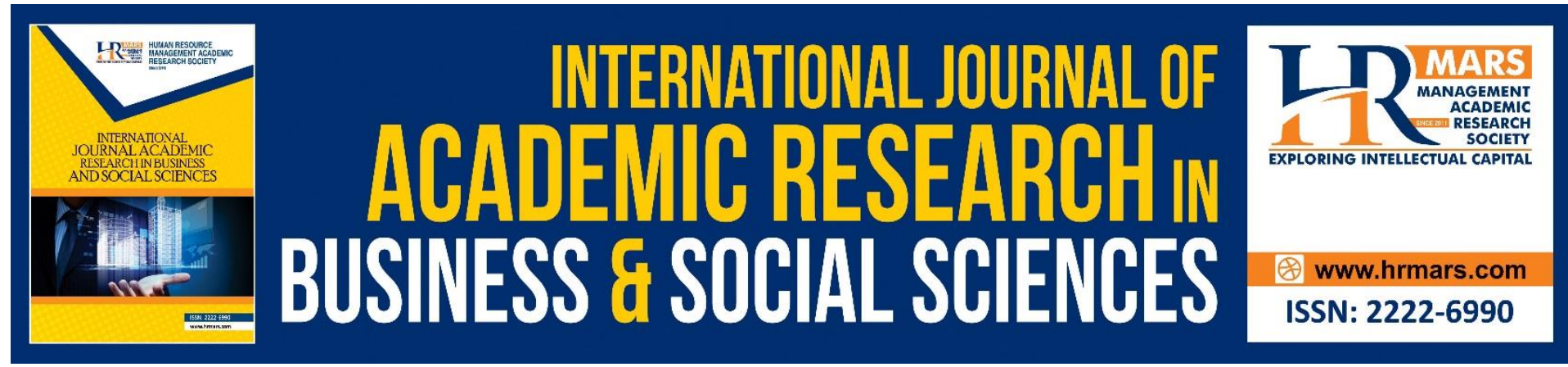

\title{
To Recycle or Not to Recycle: Factors Affecting Recycling Intention among Residents in Semi- Dense Areas in Johor, Malaysia
}

\author{
Muhammad Majid, Mohamad Faizal Ramli, Basri Badyalina, \\ Fatin Farazh Ya'acob, Ahmad Faiz Ghazali \\ Universiti Teknologi MARA (UiTM), Cawangan Johor, Kampus Segamat \\ Email: muhdmajid@uitm.edu.my
}

\begin{abstract}
This study explored the factors that influence recycling intentions among residents in semidense areas in Johor, Malaysia. Recycling is one of the strategies used to reduce the reliance on landfills, as further inaction will lead to landfills reaching maximum capacity. In this study, 299 respondents who live in semi-dense areas in Johor, Malaysia were surveyed, and the collected data was analyzed using SPSS. According to the results, attitude, perceived behavioral control (PBC), moral norm, and consequences awareness were found to be significant toward recycling intentions. Conversely, subjective norms and perceived policy effectiveness were insignificant toward recycling intention. This result differs from previous studies that investigated recycling intentions. Even Though the results are not statistically significant, the government should continue to connect with the community actively, especially in small towns to explain the benefits of recycling to the community and environment by organizing awareness campaigns that promote recycling. These findings are expected to offer policymakers useful information to develop an effective recycling policy in Malaysia.
\end{abstract}

Keywords: Recycling, Semi-Dense Area, Policy, Malaysia, Recycling Intention

\section{Introduction}

The world now is witnessing a rise in solid waste generation, where solid waste is burned or sent to landfills. However, both methods are not a great solution due to the increasing amount of waste produced, leading to pollution and the contamination of land and water bodies. Surprisingly in 2016, cities worldwide had generated around 2.01 billion tons of solid waste, amounting to 740 grams of waste per person each day (Noordin, 2020). Furthermore, it is estimated that by 2050 , the annual waste produced will increase by $70 \%$ to 3.4 billion tons because of rapid population growth and urbanization.

In 2019, it was reported that Malaysia had generated 38000 tons of waste daily, and only $24 \%$ was recycled or separated, and $76 \%$ of the waste produced were sent to landfills (Noordin, 2020). Furthermore, while most Malaysians are aware of the negative consequences of single-use plastics, Malaysians believed that the government was solely responsible for avoiding environmental hazards (Yusof, Mazni \& Kadir, 2019). A study conducted by Ipsos Malaysia found that $56 \%$ of respondents were worried about the plastic 
usage and sustainability issue and wanted to see efforts carried out to overcome it. Nevertheless, only $44 \%$ of Malaysians were aware of the "Roadmap toward Zero Single-Use Plastic" initiative organized by the Ministry of Energy, Science, Technology, and Climate Change (MESTECC) in Malaysian (Yusof et al., 2019).

For decades, issues on waste management have been the financial and administrative responsibility of the government. However, the system seems incompetent and unable to cope with the rising plastic and packaging generation (Lee, 2021). Wan Ishak (2020) stated that the waste segregation initiative undertaken by the government has yet to yield any results, and the implementation should be streamlined to meet the target. Furthermore, Mokhtar (2016) stated that the awareness about recycling among Malaysians is limited. Additional efforts must be carried out by both the government and private sectors to increase knowledge on recycling. Several studies have investigated recycling intentions that focused on big cities or densely populated cities such as Hong Kong (Aboelmaged, 2020; Chan \& Bishop, 2013; Wan et al., 2013, 2017, 2021; Zhang et al., 2019).

Moreover, recycling intentions have been studied by Mahmud and Osman (2010) and Mamun et al. (2018). This study explores the interaction impacts of recycling attitude, subjective norms, behavior control, moral norm, awareness, and perceived policy effectiveness toward recycling intention of respondents in a semi-dense area in Johor, Malaysia. This study aims to elucidate the recycling intentions of Malaysians living in semidense areas, which can benefit policymakers in policy formulation. Hence, this study investigates the impact of recycling attitudes, behavior, and perceived policy efficacy on recycling intentions in semi-dense areas.

\section{Literature Review and Conceptual Framework}

Recycling Intention

Recycling intention is defined as the self-commitment of an individual toward recycling (Park \& $\mathrm{Ha}, 2014$ ). Various literature has explored recycling intention by understanding the models and variables involved based on a social psychology perspective (Wan et al., 2017). An individual's attitude can be defined as the subjective assessment of behavior and the likelihood to act on the behavior. Subjective norms are social pressures exerted onto an individual to carry out a particular behavior that would impact behavioral intention (Wan et al., 2017). Additionally, the self-awareness of the implications of actions is known as awareness of consequences. This element is an influence on recycling intentions (Chen \& Tung, 2009).

Moral norms can be defined as the belief of right or wrong toward performing a particular behavior. It can also be described as a feeling of commitment that people hold that supersedes certain behaviors' obligation (Bamberg \& Moser, 2007). Moreover, the perceived policy effectiveness is the positive or negative perception of an individual toward a specific policy (Wan et al., 2013).

Despite this, limited study has been carried out to investigate the influence of perceived policy efficacy in predicting recycling behavior (Wan, Shen \& Yu, 2014). Furthermore, Wan and Shen (2013) postulated that people with a positive attitude were more likely to engage in recycling behavior. The government should implement initiatives to motivate more people to recycle. 


\section{Recycling Attitude}

Attitude refers to the viewpoint or feeling on performing the intended behavior (Mahmud \& Osman, 2010; Sulaiman, Shiau \& Yi, 2019) and behavioral belief (Pikturniene \& Baumle, 2016). Attitude can be explained based on the perspective of an individual toward recycling. A positive perspective on recycling activities (good, useful, rewarding, responsible, sensible or hygienic) will encourage an individual to recycle their waste (Wan, Geoffrey \& Ann, 2014). Previous studies have discussed attitude as a factor that encourages an individual intention to recycle (Mahmud \& Osman, 2010; Pamuk \& Kahriman-Pamuk, 2019; Sulaiman et al., 2019; Wan et al., 2014).

A study conducted by Sulaiman et al. (2019) postulated that attitude has a positive correlation with the intention to recycle in Malaysian students. This is supported by Pamuk and Kahriman-Pamuk (2019), which indicated a significant relationship between attitude and recycling attention among teachers in Turkey. Conversely, a study carried out by Mahmud and Osman (2010) among secondary school students in Malaysia indicated that attitude has a negative, significant relationship toward recycling intention. That attitude will influence the intentions of an adult. In addition, Tonglet (2003) postulated that there is no guarantee that an individual with a positive attitude will participate in recycling activities. A study by Lim, Tong, and Ahmed (2018) among households in Melaka, Malaysia determined that attitude has a positive relationship toward intention to recycle yet the participation among households was low due to a lack of knowledge and awareness of the implications of recycling. Thus, the subsequent hypothesis is suggested:

H1. There is a positive relationship between attitude and recycling intention.

\subsection{Subjective Norm}

Subjective norm indicates that the behavior of an individual is influenced by social pressure from family members, friends, and other important people who expect an individual to recycle (Wan et al., 2014). Pikturniene and Baumle (2016) postulated that subjective norms are pressure from parents, friends, colleagues, neighbors, the government, and experts to participate in recycling activities that can influence an individual's participation. According to Arvidsson and Kling (2018), those who did not participate in recycling activities felt judged, ashamed, and embarrassed due to societal pressure. This study also elucidated that the lack of pressure from the family members and friends demotivated individuals from recycling. Thus, family and friends play important roles in influencing individual behavior. This is further supported by Bruvoll, Halvorsen and Nyborg (2002), which noted that people believed that not recycling waste will impact their reputation.

Several studies investigated the relationship between subjective norm and the intention to recycle (Mahmud \& Osman, 2010; Sulaiman et al., 2019; Pamuk \& KahrimanPamuk, 2019). A study carried out by Sulaiman et al. (2019) determined that subjective norm correlates with the intention to recycle among students in Malaysia. Pamuk and KahrimanPamuk (2019) also postulated that subjective norm is a significant factor that influences teachers in Turkey to recycle recyclable waste. Conversely, a study conducted by Pikturniene and Baumle (2016) in Lithuania determined that subjective norm did not have a significant relationship with intention. Only two factors, attitude and recent recycling behavior contributed to the intention of recycling. Therefore, the following hypothesis is proposed:

$\mathrm{H} 2$. There is a positive relationship between subjective norms and recycling intention. 


\subsection{Perceived Behavioral Control (PBC)}

The Theory of Planned Behavioral (TPB) offers a theoretical framework for analyzing the factors that systematically affect behavioral decisions has been used to study a variety of environmentally friendly behaviors, including recycling (Davis et al., 2005), the implementation of sustainable agriculture practices (Beedle \& Rehman, 2000), and composting (Taylor \& Todd, 1995). This theory is also influenced by attitude, subjective standards, and perceived behavior (Armitage \& Conner, 2001).

According to Ajzen (1991) and Fishbein and Ajzen (1975), PBC represents the previous familiarity with the success of behavior and potential barriers to behavior. As a result, the more confident a person is, the higher the tendency to conduct a behavior. Furthermore, PBC also refers to individual assessment of the difficulty levels in performing a behavior, and requires personal convictions to regulate or execute the actions (Ajzen, 1991, 2005; Walsh et al., 2009).

PBC is also interpreted as an individual's confidence in the availability of opportunities and resources to engage in recycling activities. Many recycling studies rely on PBC (Bezzina \& Dimech, 2011; Chu \& Chiu, 2003; Khan, Ahmed \& Najmi, 2019; Wang et al., 2018; Valle et al., 2005; Zhang \& Rasheed, 2020) as it is shown to be a significant factor in predicting the purpose of an individual which influences their actions and the likelihood of performing a behavior (Osman, 2014). Previous studies carried out postulate that PBC influences the propensity to buy green items (Michaelidou \& Hassan, 2010), to visit green hotels (Han, Hsu \& Sheu, 2010), revisit green hotels (Han \& Kim, 2010), and recycle household waste (Han \& Kim, 2010).

A study carried out by Tih and Zainol (2012), indicated that PBC is the most important predictor of recycling intention and word-of-mouth. PBC is also the willingness of an individual to engage in green practices like recycling and encouraging others to recycle is strongly influenced by self-confidence in carrying out such tasks. Consequently, the versatility of green practices should be emphasized in the green campaign to inspire people to engage in green practices. It will be easier for an individual to participate in the behavior once they have gained faith in performing green tasks. Conversely, previous studies carried out by Han, Hsu, and Sheu (2010) and Han and Kim (2010), perceived that behavioral regulation appears to have the least effect on green intentions and fails to demonstrate a substantial effect (Chen \& Tung, 2008; Schubert, 2008).

Perceived behavioral control is the weakest psychological element in predicting recycling intention, according to Amini et al. (2014). In addition, the findings show that punishment has a considerable impact on perceived behavioral control. Given the significant influence of fines on perceived behavioral control and the lack of a relationship between behavioral control and recycling intention, penalty-based policies and programs should be targeted to promote positive perceptions among households to increase PBC. In developing countries, PBC is an irrelevant indicator of the intention to recycle due to the lack of infrastructure, services, and funding that deters individuals from engaging in recycling (Khan et al., 2019). Subsequently, the following hypothesis is proposed:

$\mathrm{H} 3$. There is a positive relationship between $\mathrm{PBC}$ and recycling intention.

\subsection{Moral Norm}

One of the commonly used predictors used to improve the predictive potential of the standard TPB constructs is moral norms (Chan \& Bishop, 2013; Davis et al., 2006; Tonglet et al., 2004). Moral norms are characterized as the personal concern of an individual about moral 
obligations like a person's legal and social responsibilities (Kroneberg et al., 2010; Lizin et al., 2017; Wan et al., 2014).

Several studies undertaken on recycling actions indicate a positive association between moral norms and return intention and are considered an essential factor in understanding the purpose of an individual (Chen \& Tung, 2010; Chu \& Chiu, 2003; Park \& Ha, 2014). Nevertheless, moral norms were found to be negligible predictors of recycling in developing countries in a study conducted by Khan et al. (2019). This is because consumers have a lower standard of living and do not participate in recycling activities regularly despite having knowledge and awareness about recycling.

People will get monetary incentives for participating in recycling activities. However, there is lower motivation to recycle because it provides little personal benefit. People are also aware of the importance of recycling and the possible risks posed by plastic to the environment while considering the relationship between moral standards and recycling. Conversely, households would have to bear disposal costs if the responsible authorities do not carry out adequate recycling efforts. As a result, the relationship was found to be insignificant. Therefore, the following hypothesis is proposed:

H4. There is a relationship between moral norms and recycling intention.

\subsection{Consequences}

A study conducted by Calvin et al. (2013) inferred that awareness of consequences is one of the main factors that can influence recycling intentions that also triggered the relationship between behavior and personal norms. Furthermore, Davies et al. (2002) determined that a greater awareness of appropriate behavior can affect the recycling intention. In addition, several other studies carried out on awareness of consequences were found to be significant toward recycling intention (Chen \& Tung, 2010; Tonglet et al., 2004). The key to overcoming these challenges is awareness. In developing countries, Setiawan et al. (2018) developed a randomized conjoined analysis which discovered that various published articles have sought to investigate household preferences for waste management systems (Hainmuller et al., 2014, Yuan \& Yabe, 2015). In addition, several studies looked at the awareness consequences as a construct (e.g., Chen \& Tung, 2010; Tonglet et al., 2004; Wan et al., 2012). The attitude of individuals about recycling (good, beneficial, and pleasurable) is operationalized in this study. In contrast, awareness of repercussions highlights the comprehension on the implications of recycling behavior (Wan et al., 2013).

According to Bamberg and Schmidt (2003), the individual who is a "utility maximizing actor" would choose the option with the greatest favorable behavioral consequences. Moreover, Ajzen (1991) measured attitudes as the beliefs of an individual about the outcome of an action based on self-assessment. Consequently, attitudes in the TPB are linked to consequences awareness. Hence, the following hypothesis is suggested:

H5. There is a positive relationship between consequences and recycling intention.

\subsection{Perceived Policy Effectiveness}

Several aspects of environmental contamination require government and citizen attention, such as the emissions and cost reduction case studies (Talebian et al., 2021). Environmental awareness must be cultivated in children through education to raise environmental consciousness. Society does not need to wait for calamities to begin thinking about waste management and how it may aid in preserving the world. Furthermore, Fu et al. (2020) described the moderating effects of perceived policy effectiveness and discovered a 
knowledge gap about the environment. Citizens with a high level of environmental knowledge are more likely to act in environmentally beneficial ways. An increase in recycling practices by households can help the government conserve and decrease selected residential areas' efforts to aid waste administration.

A study conducted in Hong Kong by Wan, Shen and Yu (2013) illustrated that recycling intention can be influenced by perceived policy effectiveness and other factors like subjective norms, PBC, moral norms, and consequences awareness influence recycling intention. Furthermore, the study highlighted that self-reported recycling behavior or direct and indirect behavior like support for policy measures affect recycling intention. The government should offer more recycling bins and guidelines on recycling activities to enable and promote recycling. Based on the above discussion, the following hypothesis is suggested:

H6. There is a positive relationship between perceived policy effectiveness and recycling intention.

\subsection{Measurement Model}

The measurement model used in this study is illustrated in Figure 1. Six predictors are hypothesized to influence recycling intentions.

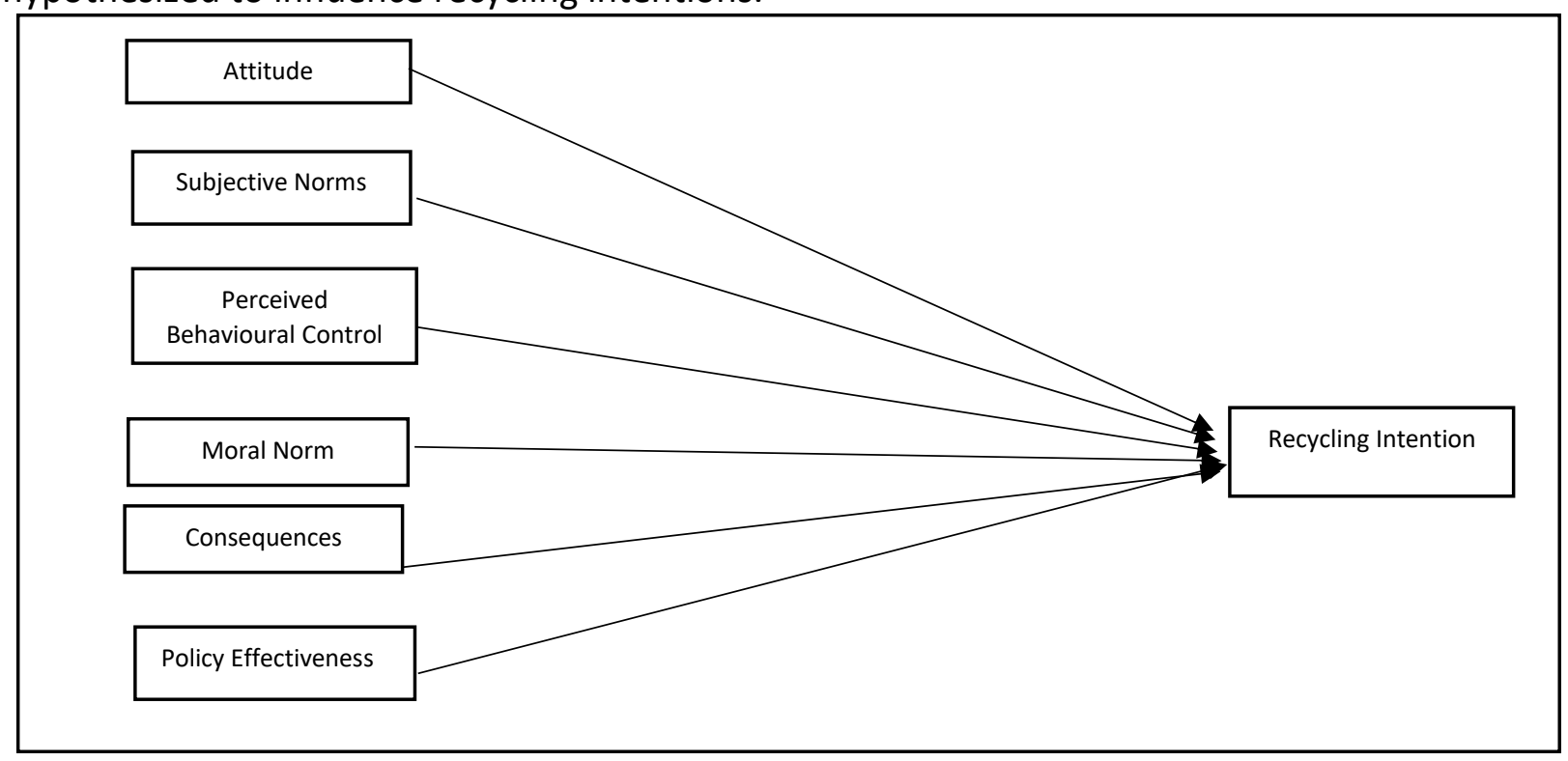

Figure 1: The research framework used in this study

\section{Questionnaire Design and Data Collection}

The questionnaire used in this study was adapted from Wan et al. (2013). The variables and components of the proposed model were measured using a five-point Likert scale, where a score of ' 5 ' represents a good perspective and a score of ' 1 ' indicates a negative perception.

In addition, the questionnaire consisted of the six independent variables consisting of attitude, subjective norm, perceived behavioral control, moral norm, consequences, and perceived policy effectiveness. Furthermore, the bilingual (English and Malay) questionnaire also inquired about the demographic information (age group, gender, education level, occupation, income range, and current area of residence) of the respondents hence; pretesting was implemented to enhance the viability if the study by refining the wordings on the questionnaire. 
The online questionnaires were distributed to more than 350 respondents in eleven semi-dense areas in Johor, Malaysia however, only 299 questionnaires were usable (Table 1).

\section{Empirical Results and Findings}

The demographic information of respondents is presented in Table 1. The background data collected from the respondents revealed that a majority of respondents $(76.6 \%)$ were between 21-30 years old. The gender distribution indicated that most respondents were female (72.6\%). In terms of education level, $68.6 \%$ of respondents have at least a Bachelor's degree. Most of the respondents were students (78.3\%) and earned less than RM 1000 (75.3\%). This result indicated that most of the respondents lived in Jementah (48.2\%).

Table 1: The Sociodemographic Profile of Respondents

\begin{tabular}{|c|c|c|}
\hline Demographic Variable & $\mathbf{N}$ & Percentage (\%) \\
\hline \multicolumn{3}{|l|}{ Age } \\
\hline Under 20 & 14 & 4.7 \\
\hline $21-30$ & 229 & 76.6 \\
\hline $31-40$ & 38 & 12.7 \\
\hline $41-50$ & 13 & 4.3 \\
\hline 51 and above & 5 & 1.7 \\
\hline \multicolumn{3}{|l|}{ Gender } \\
\hline Male & 82 & 27.4 \\
\hline Female & 217 & 72.6 \\
\hline \multicolumn{3}{|l|}{ Education Level } \\
\hline SPM & 5 & 1.7 \\
\hline Diploma & 89 & 29.8 \\
\hline Bachelor Degree & 151 & 50.5 \\
\hline Master's Degree & 26 & 8.7 \\
\hline PhD & 25 & 8.4 \\
\hline Others & 3 & 1.0 \\
\hline \multicolumn{3}{|l|}{ Occupation } \\
\hline Employed (Private Sector) & 0 & 0 \\
\hline Employed (Public Sector) & 61 & 20.4 \\
\hline Self-employed & 0 & 0 \\
\hline Student & 234 & 78.3 \\
\hline Retired & 0 & 0 \\
\hline Unable to work & 2 & 0.7 \\
\hline Others & 2 & 0.7 \\
\hline \multicolumn{3}{|l|}{ Monthly Income } \\
\hline Less than RM 1,000 & 225 & 75.3 \\
\hline RM 1,000 to RM 2000 & 13 & 4.3 \\
\hline RM 2,001 to RM 3000 & 8 & 2.7 \\
\hline RM 3,001 to RM 4000 & 3 & 1.0 \\
\hline RM 4,001 to RM 5000 & 2 & 0.7 \\
\hline
\end{tabular}




\begin{tabular}{ccc}
\hline RM 5,001 to RM 6000 & 3 & 1.0 \\
RM 6,001 to RM 7000 & 15 & 5.0 \\
More than RM 7001 & 30 & 10.0 \\
& & \\
Current Area of Residence & & \\
Labis & 6 & 2.0 \\
Buloh Kasap & 11 & 3.7 \\
Gemas Baharu & 3 & 1.0 \\
Gemereh & 17 & 5.7 \\
Jabi & 2 & 0.7 \\
Jementah & 144 & 48.2 \\
Pogoh & 1 & 0.3 \\
Sg. Segamat & 31 & 10.4 \\
Lain-lain & 84 & 28.1 \\
Sermin & 0 & 0 \\
Bekok & 0 & 0 \\
Chaah & 0 & 0 \\
\hline
\end{tabular}

\subsection{Data Analysis}

The reliability of assumptions for all constructs was established using Cronbach's alpha, and all the constructs exceeded the cut-off point of 0.70 , indicating that the dependability assumptions were met (Appendix A). Table 3 shows the multiple regression correlation coefficients $(R)$, which indicated a linear relationship between attitude, subjective norms, PBC, moral norms, consequences, perceived policy effectiveness, and recycling intention.

The six independent factors (attitude, subjective norms, PBC, moral standards, consequences, and perceived policy efficacy) only accounted for $60.7 \%$ of the variation in recycling intention. Conversely, other factors that were not covered in this study could account for the remaining unexplained $39.3 \%$.

Table 3: Regression summary on independent variables and recycling intention

\begin{tabular}{ccccc}
\hline Model & $\mathbf{R}$ & $\mathbf{R}$ & $\begin{array}{c}\text { Adjusted R } \\
\text { Square }\end{array}$ & $\begin{array}{c}\text { Std. Error of } \\
\text { the Estimate }\end{array}$ \\
\hline $\begin{array}{c}\text { Predictors: (Constant), Attitude, } \\
\text { Subjective Norms, Perceived Behavioral } \\
\text { Control, Moral Norm, Consequences. }\end{array}$ & $0.784 a$ & 0.615 & 0.607 & 0.51536 \\
\hline
\end{tabular}

Table 4 indicates Spearman's coefficient result which suggests a 0.397 correlation between attitude and recycling intention $(p=0.05)$. The findings reveal a strong, positive link between attitude and the intention to recycle. This result is consistent with the study of Sulaiman et al. (2019) on Malaysian students' perspectives that reported a positive correlation between attitude and the intention to recycle. Moreover, the results are corroborated by Lim et al. (2018) that attitude has a positive relationship toward the intention to recycle in households in Melaka, Malaysia.

In addition, there is a positive, moderate relationship between subjective norms, PBC, and recycling intention $(0.625 ; p<0.05$ and $0.678 ; p<0.05)$, respectively. The result is consistent with previous studies that determined the relationship between subjective norm and the intention to recycle (Mahmud \& Osman, 2010; Pamuk \& Kahriman-Pamuk, 2019; 
Sulaiman et al., 2019). Furthermore, the result obtained is in line with Michaelidou and Hassan (2010) which postulated that PBC influences the intention to recycle household waste. In addition, a recent study conducted by Ting et al (2020) indicates that attitude, subjective norm and PBC influence plastic usage behavior among Malaysians.

The results obtained indicate a positive, strong relationship between moral norms and recycling intention $(0.727 ; p<0.05)$. Studies on recycling intention found a positive association between moral norms and return intention and stress that moral norms must be considered when understanding the purpose of an individual (Chen \& Tung, 2010; Chu \& Chiu, 2003; Park \& Ha, 2014).

There is a positive, moderate relationship between consequences and policy effectiveness toward recycling intention (0.423; $p<0.05$ and $0.536 ; p<0.05)$, respectively as shown in Table 4. The result is corroborated by Wan et al. (2013), which elucidates the influence of policy effectiveness on recycling intention. Several studies carried out about consequences awareness showed statistically significant relationships in describing recycling behavior intention (Tonglet et al., 2004; Wan et al., 2013). 
Table 4: Correlation between attitude, subjective norms, PBC, moral norms, consequences awareness, perceived policy effectiveness, and recycling intention.

\begin{tabular}{|c|c|c|}
\hline \multicolumn{3}{|c|}{ Correlations } \\
\hline & & Recycling Intention \\
\hline \multirow[t]{3}{*}{ Attitude } & Pearson Correlation & $0.397^{* *}$ \\
\hline & Sig. (2-tailed) & 0.000 \\
\hline & $\mathrm{N}$ & 299 \\
\hline \multirow[t]{3}{*}{ Subjective Norms } & Pearson Correlation & $0.625^{* *}$ \\
\hline & Sig. (2-tailed) & 0.000 \\
\hline & $\mathrm{N}$ & 299 \\
\hline \multirow[t]{3}{*}{ Perceived behavioral Control } & Pearson Correlation & $0.678^{* *}$ \\
\hline & Sig. (2-tailed) & 0.000 \\
\hline & $\mathrm{N}$ & 299 \\
\hline \multirow[t]{3}{*}{ Moral Norms } & Pearson Correlation & $0.727^{* *}$ \\
\hline & Sig. (2-tailed) & 0.000 \\
\hline & $\mathrm{N}$ & 299 \\
\hline \multirow[t]{3}{*}{ Consequences Awareness } & Pearson Correlation & $0.423^{* *}$ \\
\hline & Sig. (2-tailed) & 0.000 \\
\hline & $\mathrm{N}$ & 299 \\
\hline \multirow[t]{3}{*}{ Policy Effectiveness } & Pearson Correlation & $0.536^{* *}$ \\
\hline & Sig. (2-tailed) & 0.000 \\
\hline & $\mathrm{N}$ & 299 \\
\hline \multirow[t]{3}{*}{ Recycling Intention } & Pearson Correlation & 1 \\
\hline & Sig. (2-tailed) & \\
\hline & $\mathrm{N}$ & 299 \\
\hline **. Correlation is sig & iificant at the 0.01 leve & (2-tailed) \\
\hline
\end{tabular}

Based on the results obtained, subjective norms $(B=0.100 ; t=1.796 ; P>0.05)$ and perceived policy effectiveness $(B=0.093 ; t=1.915 ; P>0.05)$ did not have a statistically significant relationship with recycling intention. Nevertheless, attitude $(B=0.117, t=2.776$; $p<0.05) ; P B C(B=0.190, t=2.993 ; p<0.05)$, moral norms $(B=0.400, t=7.030 ; p<0.05)$, and consequences awareness $(B=0.086, t=1.990 ; p<0.05)$ have a statistically significant relative effect on recycling intention. However, a study conducted by Pikturniene and Baumle (2016) determined that subjective norm had no significant relationship with intention. Conversely, the results showed that perceived policy effectiveness has an insignificant relationship with recycling intention. The insignificant relationship could be attributed to the lack of or inefficient guidelines on recycling by government agencies. Additionally, government agencies should continue to promote the benefits of recycling, and the policy should encourage people to recycle. Overall, perceived policy effectiveness can be a strong predictor 
toward recycling intention. Still, its effects may not be strong enough in the context of this study as only one district was studied.

This result is consistent with Pamuk and Kahriman-Pamuk (2019) that attitude has a significant relationship toward the recycling attention attitudes significantly influence consumer intentions (Sari, Masruroh \& Asih, 2021). The result postulates that PBC is a significant factor that influences recycling intention. This is supported by studies carried out by Pamuk and Pamuk (2019) and Michaelidou and Hassan (2010) that found that PBC influences recycling intentions and the intention to buy green goods, respectively. Furthermore, this finding is consistent with a study carried out by Poskus (2015) that indicated that moral rules improved recycling behavioral variance.

These findings suggest that researchers should include moral norms as an additional predictor variable when applying the TPB to investigate recycling and sustainable behavior. Similarly, various studies also observed that moral norms were significant predictors (Chen \& Tung, 2010; Valle et al., 2005). The results showed that $\mathrm{H1}, \mathrm{H} 3, \mathrm{H} 4$, and $\mathrm{H} 5$ were supported, and $\mathrm{H} 2$ and $\mathrm{H} 6$ were rejected (Table 5).

Table 5: Results of the hypothesis of the study

\begin{tabular}{|c|c|c|c|c|c|}
\hline $\begin{array}{l}\text { Standardized } \\
\text { Coefficients }\end{array}$ & & & & & \\
\hline \multirow[t]{7}{*}{1} & $\begin{array}{c}\text { Model } \\
\text { Constant }\end{array}$ & Beta & $\begin{array}{c}\mathbf{t} \\
- \\
2.494\end{array}$ & $\begin{array}{c}\text { Sig. } \\
0.013\end{array}$ & Result \\
\hline & Attitude & 0.117 & 2.776 & 0.006 & Supported \\
\hline & $\begin{array}{l}\text { Subjective } \\
\text { Norms }\end{array}$ & 0.100 & 1.796 & 0.073 & $\begin{array}{c}\text { Not } \\
\text { supported }\end{array}$ \\
\hline & $\begin{array}{c}\text { Perceived } \\
\text { Behavioral } \\
\text { Control }\end{array}$ & 0.190 & 2.993 & 0.003 & Supported \\
\hline & Moral Norm & 0.400 & 7.030 & 0.000 & Supported \\
\hline & $\begin{array}{c}\text { Consequences } \\
\text { Awareness }\end{array}$ & 0.086 & 1.990 & 0.048 & Supported \\
\hline & $\begin{array}{l}\text { Perceived } \\
\text { Policy } \\
\text { Effectiveness } \\
\text { Dependent } \\
\text { Variable: } \\
\text { Recycling } \\
\text { Intention }\end{array}$ & 0.093 & 1.915 & 0.057 & $\begin{array}{c}\text { Not } \\
\text { supported }\end{array}$ \\
\hline
\end{tabular}

\section{Limitations and Future Research}

There are several limitations in this study that should be addressed in future research. Firstly, this study used a relatively small sample taken in semi-dense areas in Johor, Malaysia. Although this study intended to cover a broader population, most of the respondents were younger than 30 years old, and a majority of the respondents were students. Future studies should compare other respondents from semi-dense areas or compare between semi-dense and dense areas. In addition, the findings of this study may not represent other areas, countries, or contexts and cannot be generalized. Future research should also consider other 
variables like the commitment to the environment, moral obligation, enforcement, and ecoliteracy to understand recycling intentions better.

\section{Discussion and Conclusion}

This study attempted to investigate the factors that influence recycling intention, particularly in semi-dense areas in Johor, Malaysia by adapting a model developed by Wan et al. (2013). The results showed that subjective norms and perceive policy effectiveness are not statistically significant towards recycling intention. This result differs from previous studies that investigated recycling intentions. Although the results are not statistically significant, the government should continue to engage with the community actively, especially in small towns to explain the benefits of recycling to the community and environment by organizing awareness campaigns that promote recycling.

Public participation in recycling campaigns can increase the sense of ownership resulting in participants encouraging their family members, friends, and neighbors to recycle. Furthermore, the government should provide more recycling bins and clear procedures for recycling activities for people in small towns. Simple guidelines or simplified infographics that are easy to understand and written in multiple languages will attract people from different age groups, and backgrounds to read and understand the guidelines.

Based on the results, attitude, perceived behavioral control, moral norm, and consequences awareness were significant with recycling intention. In addition, among all the variables studied, moral norms influenced recycling intention the strongest followed by perceived behavior control, and subjective norms, respectively. In conclusion, these findings can aid policymakers to understand better the factors that influence recycling behavior and intentions among semi-dense households.

\section{Acknowledgement}

This study is supported by a grant from Universiti Teknologi MARA (UiTM) Cawangan Johor. Geran Penyelidikan Bestari Fasa 2/2020, Rujukan: 600-UiTMCJ (PJIA. 5/2).

\section{References}

"Drastic Changes Needed". (2020). Drastic changes needed for country's solid waste management. Retrieved from Free Malaysia Today:

https://www.freemalaysiatoday.com/category/nation/2020/12/31/drastic-changesneeded-for-countrys-solid-waste-management.

Aboelmaged, M. (2021). E-waste recycling behaviour: An integration of recycling habits into the theory of planned behaviour. Journal of Cleaner Production, 278, 124182.

Ajzen, I. (1991). The theory of planned behavior. Organizational behavior and human decision processes, 50(2), 179-211.

Ajzen, I. (2005). Attitudes, personality and behaviour: McGraw-Hill Education (UK).

Al Mamun, A., Mohiuddin, M., Ahmad, G. B., Thurasamy, R., \& Fazal, S. A. (2018). Recycling intention and behavior among low-income households. Sustainability, 10(7), 2407.

Amini, F., Ahmad, J., \& Ambali, A. R. (2014). The influence of reward and penalty on households' recycling intention. APCBEE procedia, 10, 187-192.

Armitage, C. J., \& Conner, M. (2001). Efficacy of the theory of planned behaviour: A metaanalytic review. British journal of social psychology, 40(4), 471-499. 
Arvidsson, E., \& Kling, V. (2018). Factors influencing the intention to perform in-store recycling: A qualitative study applying the Theory of Planned Behaviour to the Swedish fashion industry, Bachelor Thesis in Business Administration, Jonkoping University.

Bamberg, S., \& Möser, G. (2007). Twenty years after Hines, Hungerford, and Tomera: A new meta-analysis of psycho-social determinants of pro-environmental behaviour. Journal of environmental psychology, 27(1), 14-25.

Bamberg, S., \& Schmidt, P. (2003). Incentives, morality, or habit? Predicting students' car use for university routes with the models of Ajzen, Schwartz, and Triandis. Environment and behavior, 35(2), 264-285.

Beedell, J., \& Rehman, T. (2000). Using social-psychology models to understand farmers' conservation behaviour. Journal of rural studies, 16(1), 117-127.

Bezzina, F. H., \& Dimech, S. (2011). Investigating the determinants of recycling behaviour in Malta. Management of Environmental Quality: An International Journal.

Boldero, J. (1995). The prediction of household recycling of newspapers: The role of attitudes, intentions, and situational factors 1. Journal of Applied Social Psychology, 25(5), 440462.

Bruvoll, A., Halvorsen, B., \& Nyborg, K. (2002). Households' recycling efforts. Resources, Conservation and recycling, 36(4), 337-354.

Chan, L., \& Bishop, B. (2013). A moral basis for recycling: Extending the theory of planned behaviour. Journal of environmental psychology, 36, 96-102.

Chen, M., \& Tung, P. (2008). The Moderating Effects of Perceived Lack of Facilities and Implementation Performance Of Policies On Consumers' Recycling Intentions. Retrieved on December, 11, 2010.

Chen, M.-F., \& Tung, P.-J. (2010). The moderating effect of perceived lack of facilities on consumers' recycling intentions. Environment and behavior, 42(6), 824-844.

Chu, P. Y., \& Chiu, J. F. (2003). Factors influencing household waste recycling behavior: Test of an integrated model 1. Journal of Applied Social Psychology, 33(3), 604-626.

Davies, J., Foxall, G. R., \& Pallister, J. (2002). Beyond the intention-behaviour mythology: an integrated model of recycling. Marketing theory, 2(1), 29-113.

Davis, G., Phillips, P. S., Read, A. D., \& lida, Y. (2006). Demonstrating the need for the development of internal research capacity: Understanding recycling participation using the Theory of Planned Behaviour in West Oxfordshire, UK. Resources, Conservation and recycling, 46(2), 115-127.

De Jaeger, S., Eyckmans, J., Rogge, N., \& Van Puyenbroeck, T. (2011). Wasteful waste-reducing policies? The impact of waste reduction policy instruments on collection and processing costs of municipal solid waste. Waste management, 31(7), 1429-1440.

Fishbein, M., Ajzen, I., \& Belief, A. (1975). Intention and behavior: An introduction to theory and research. In: Addison-Wesley, Reading, MA.

Fu, L., Sun, Z., Zha, L., Liu, F., He, L., Sun, X., \& Jing, X. (2020). Environmental awareness and pro-environmental behavior within china's road freight transportation industry: Moderating role of perceived policy effectiveness. Journal of Cleaner Production, 252, 119796.

Goh, M.L., David, Y.K.T., \& Ahmed, E.M. (2018). Exploring Households' Recycling Behaviour in a World Heritage City, Melaka. Jurnal Pengurusan, 54(2018) 27- 38.

Guo, Y., \& He, S. (2020). Does confidence matter for economic growth? An analysis from the perspective of policy effectiveness. International Review of Economics \& Finance, 69, 1-19. 
Gussmann, G., \& Hinkel, J. (2021). A framework for assessing the potential effectiveness of adaptation policies: Coastal risks and sea-level rise in the Maldives. Environmental Science \& Policy, 115, 35-42.

Hainmueller, J., Hopkins, D. J., \& Yamamoto, T. (2014). Causal inference in conjoint analysis: Understanding multidimensional choices via stated preference experiments. Political analysis, 22(1), 1-30.

Han, H., Hsu, L.-T. J., Lee, J.-S., \& Sheu, C. (2011). Are lodging customers ready to go green? An examination of attitudes, demographics, and eco-friendly intentions. International journal of hospitality management, 30(2), 345-355.

Han, H., \& Kim, Y. (2010). An investigation of green hotel customers' decision formation: Developing an extended model of the theory of planned behavior. International journal of hospitality management, 29(4), 659-668.

Ibrahim, A. (2020). Higher recycling rate will help put end to plastic waste pollution.

Retrieved from New Straits Times:

https://www.nst.com.my/opinion/columnists/2020/08/614016/higher-recyclingrate-will-help-put-end-plastic-waste

Khan, F., Ahmed, W., \& Najmi, A. (2019). Understanding consumers' behavior intentions towards dealing with the plastic waste: Perspective of a developing country. Resources, Conservation and recycling, 142, 49-58.

Knussen, C., Yule, F., MacKenzie, J., \& Wells, M. (2004). An analysis of intentions to recycle household waste: The roles of past behaviour, perceived habit, and perceived lack of facilities. Journal of environmental psychology, 24(2), 237-246.

Kroneberg, C., Heintze, I., \& Mehlkop, G. (2010). The interplay of moral norms and instrumental incentives in crime causation. Criminology, 48(1), 259-294.

Ling, G. M., Tong, D. Y. K., \& Ahmed, E. M. (2018). Exploring households' recycling behaviour in a world heritage city, Melaka. Jurnal Pengurusan (UKM Journal of Management), 54.

Lizin, S., Van Dael, M., \& Van Passel, S. (2017). Battery pack recycling: Behaviour change interventions derived from an integrative theory of planned behaviour study. Resources, Conservation and recycling, 122, 66-82.

Mahmud, S. N. D., \& Osman, K. (2010). The determinants of recycling intention behavior among the Malaysian school students: an application of theory of planned behaviour. Procedia-Social and Behavioral Sciences, 9, 119-124.

Michaelidou, N., \& Hassan, L. M. (2010). Modeling the factors affecting rural consumers' purchase of organic and free-range produce: A case study of consumers' from the Island of Arran in Scotland, UK. Food Policy, 35(2), 130-139.

Mokhtar, N. A. (2016). Malaysia masih ketinggalan dalam amalan kitar semula. Berita Harian: https://www.bharian.com.my/bhplus-old/2016/10/205639/malaysia-masihketinggalan-dalam-amalan-kitar-semula

Noordin, K. A. (2020). Solving an international waste management problem. Retrieved from The Edge Markets: https://www.theedgemarkets.com/article/solving-internationalwaste-management-problem

Osman, A., Md Isa, F., Othman, S. N., \& Jaganathan, M. (2014). Attitude towards recycling among business undergraduate students in Malaysia. American-Eurasian Journal of Sustainable Agriculture, 8(13), 6-12. 
Pamuk, S., \& Kahriman-Pamuk, D. (2019). Preservice teachers' intention to recycle and recycling behavior: the role of recycling opportunities. International Electronic Journal of Environmental Education, 9(1), 33-45.

Park, J., \& Ha, S. (2014). Understanding consumer recycling behavior: Combining the theory of planned behavior and the norm activation model. Family and consumer sciences research journal, 42(3), 278-291.

Pikturnienè, I., \& Bäumle, G. (2016). Predictors of recycling behaviour intentions among urban Lithuanian inhabitants. Journal of Business Economics and Management, 17(5), 780795.

Poškus, M. S. (2015). Predicting recycling behavior by including moral norms into the theory of planned behavior.

Rispo, A., Williams, I., \& Shaw, P. (2015). Source segregation and food waste prevention activities in high-density households in a deprived urban area. Waste management, 44, 15-27.

Sari, D. P., Masruroh, N. A., \& Asih, A. M. S. (2021). Consumer Intention to Participate in EWaste Collection Programs: A Study of Smartphone Waste in Indonesia. Sustainability, 13(5), 2759.

Schubert, F. (2008). Exploring and predicting consumers' attitudes and behaviors towards green restaurants. The Ohio State University,

Setiawan, R. P., Kaneko, S., \& Kawata, K. (2019). Impacts of pecuniary and non-pecuniary information on pro-environmental behavior: $A$ household waste collection and disposal program in Surabaya city. Waste management, 89, 322-335.

Sulaiman, N., Chan, S. W., \& Ong, Y. S. (2019). Factors influencing recycling intention among university students. International Journal of Innovative Technology and Exploring Engineering, 8(8S), 336-340.

Talebian, H., Herrera, O. E., \& Merida, W. (2021). Policy effectiveness on emissions and cost reduction for hydrogen supply chains: The case for British Columbia. International Journal of Hydrogen Energy, 46(1), 998-1011.

Taylor, S., \& Todd, P. (1995). An integrated model of waste management behavior: A test of household recycling and composting intentions. Environment and behavior, 27(5), 603-630.

Teh, A. Y., Mazni, N. S., \& Abdul Kadir , A. K. (2019, October 19). Survey reveals Malaysians concern. New Straits Times:

https://www.nst.com.my/news/nation/2019/10/531442/survey-reveals-malaysiansconcern-about-single-use-plastics

Tih, S., \& Zainol, Z. (2012). Minimizing waste and encouraging green practices. Jurnal Ekonomi Malaysia, 46(1), 157-164.

T'ing, L. C., Moorthy, K., Mei, C. Y., Yin, F. P., Ying, W. Z., Khong, C. W., . . Lin, T. Z. (2020). Determinants of 3Rs behaviour in plastic usage: A study among Malaysians. Heliyon, 6(12), e05805.

Tonglet, M., Phillips, P. S., \& Read, A. D. (2004). Using the Theory of Planned Behaviour to investigate the determinants of recycling behaviour: a case study from Brixworth, UK. Resources, Conservation and recycling, 41(3), 191-214.

Valle, P. O. D., Rebelo, E., Reis, E., \& Menezes, J. (2005). Combining behavioral theories to predict recycling involvement. Environment and behavior, 37(3), 364-396. 
Walsh, A., Edwards, H., \& Fraser, J. (2009). Attitudes and subjective norms: determinants of parents' intentions to reduce childhood fever with medications. Health education research, 24(3), 531-545.

Wan, C., Cheung, R., \& Shen, G. Q. (2012). Recycling attitude and behaviour in university campus: a case study in Hong Kong. Facilities.

Wan, C., Shen, G. Q., \& Choi, S. (2017). Experiential and instrumental attitudes: Interaction effect of attitude and subjective norm on recycling intention. Journal of environmental psychology, 50, 69-79.

Wan, C., Shen, G. Q., \& Choi, S. (2021). The place-based approach to recycling intention: Integrating place attachment into the extended theory of planned behavior. Resources, Conservation and recycling, 169, 105549.

Wan, C., Shen, G. Q., \& Yu, A. (2014). The moderating effect of perceived policy effectiveness on recycling intention. Journal of environmental psychology, 37, 55-60.

Wan, C., Shen, G. Q., \& Yu, A. (2014). The moderating effect of perceived policy effectiveness on recycling intention. Journal of environmental psychology, 37, 55-60.

Wan, C., Shen, G. Q., \& Yu, A. (2014). The role of perceived effectiveness of policy measures in predicting recycling behaviour in Hong Kong. Resources, Conservation and recycling, 83, 141-151.

Wan, C., \& Shen, G. Q. P. (2013). Perceived policy effectiveness and recycling behaviour: The missing link. Waste management(4), 783-784.

Wang, Z., Guo, D., Wang, X., Zhang, B., \& Wang, B. (2018). How does information publicity influence residents' behaviour intentions around e-waste recycling? Resources, Conservation and recycling, 133, 1-9.

Yuan, Y., \& Yabe, M. (2015). Residents' preferences for household kitchen waste source separation services in Beijing: A choice experiment approach. International journal of environmental research and public health, 12(1), 176-190.

Zhang, Y., Wu, S., \& Rasheed, M. I. (2020). Conscientiousness and smartphone recycling intention: The moderating effect of risk perception. Waste management, 101, 116125. 


\section{Appendix A}

Statement

Attitude $(\alpha=0.85)$

Recycling is good.

Kitar semula adalah amalan yang baik.

Recycling is useful.

Kitar semula adalah berguna.

Recycling is rewarding.

Kitar semula adalah bermanfaat.

Recycling is responsible.

Kitar semula adalah amalan bertanggungjawab.

Recycling is sensible.

Kitar semula adalah amalan yang wajar.

Recycling is hygienic.

Kitar semula adalah kebersihan.

Subjective Norm ( $\alpha=0.841$ )

Most people who are important to me think I should recycle.

Kebanyakan orang yang penting untuk saya fikir saya harus mengitar semula.

Most people who are important to me would approve of my recycling.

Kebanyakan orang yang penting bagi saya akan bersetuju amalan kitar semula saya.

My friends expect me to recycle household materials.

Rakan-rakan saya berharap saya mengitar semula bahan rumah.

My family expects me to recycle household materials.

Keluarga saya mengharapkan saya mengitar semula bahan rumah.

Perceived Behavioral Control (PBC) $(\alpha=0.925)$

I have plenty of opportunities to recycle.

Saya mempunyai banyak peluang untuk mengitar semula.

Recycling is convenient.

Kitar semula adalah mudah.

Recycling is easy.

Kitar semula adalah senang.

I know where to take my household waste for recycling.

Saya tahu di mana hendak membawa sampah isi rumah saya untuk dikitar semula.

I know how to recycle my household waste.

Saya tahu bagaimana mengitar semula sampah isi rumah saya.

I have enough time to sort the materials for recycling.

Saya mempunyai masa yang cukup untuk menyusun bahan untuk dikitar semula.

I have enough space to store the materials for recycling.

Saya mempunyai ruang yang cukup untuk menyimpan bahan untuk dikitar semula.

Moral Norms $(\alpha=0.881)$

I feel I should not waste anything if it could be used again.

Saya rasa saya tidak patut membuang apa-apa jika ia dapat digunakan lagi.

It would be wrong of me not to recycle my household waste.

Adalah salah bagi saya untuk tidak mengitar semula sampah rumah saya.

I would feel guilty if I did not recycle my household waste.

Saya akan berasa bersalah sekiranya saya tidak mengitar semula sampah rumah saya. 
Not recycling goes against my principles.

Tidak mengitar semula bertentangan dengan prinsip saya.

Everybody should share the responsibility to recycle household waste.

Semua orang harus mempunyai tanggungjawab untuk mengitar semula sampah isi rumah.

Consequences Awareness ( $\alpha=0.901)$

Recycling reduces pollution.

Kitar semula mengurangkan pencemaran.

Recycling reduces wasteful use of landfills.

Kitar semula mengurangkan penggunaan tapak pelupusan sampah.

Recycling conserves natural resources.

Kitar semula menjimatkan sumber semula jadi.

Recycling improves environmental quality.

Kitar semula meningkatkan kualiti alam persekitaran.

Recycling saves energy.

Kitar semula menjimatkan tenaga.

Perceived Policy Effectiveness ( $\alpha=0.861$ )

The waste separation bins provided by the Government are sufficient to facilitate recycling.

Tong pengasingan sampah yang disediakan oleh Kerajaan mencukupi untuk memudahkan kitar semula.

The Government provides clear guidelines on recycling.

Kerajaan memberikan garis panduan yang jelas mengenai kitar semula.

The Government's promotion clearly explains the benefits of recycling.

Promosi kitar semula oleh Kerajaan menerangkan dengan jelas faedah kitar semula.

The Government's policy encourages me to recycle.

Dasar Kerajaan mendorong saya untuk mengitar semula.

The Government's policy facilitates me to recycle.

Dasar Kerajaan memudahkan saya mengitar semula.

Behavioral Intention ( $\alpha=0.883$ )

I intend to recycle my recyclables in the next 4 weeks.

Saya berhasrat untuk mengitar semula barang kitar semula saya dalam 4 minggu akan datang.

I will recycle my recyclables every time I have it for disposal.

Saya akan mengitar semula barang kitar semula saya setiap kali memilikinya untuk dilupuskan.

I am willing to participate in the recycling scheme in the future.

Saya bersedia untuk menyertai skim kitar semula pada masa akan datang.

\section{Attitude}

Sikap

Recycling is good.

Kitar semula adalah amalan yang baik.

Recycling is useful.

Kitar semula adalah berguna.

Recycling is rewarding. 
Kitar semula adalah bermanfaat.

Recycling is responsible.

Kitar semula adalah amalan bertanggungjawab.

Recycling is sensible.

Kitar semula adalah amalan yang wajar.

Recycling is hygienic.

Kitar semula adalah kebersihan.

\section{Subjective Norms}

Norma Subjektif

Most people who are important to me think I should recycle.

Kebanyakan orang yang penting untuk saya fikir saya harus mengitar semula.

Most people who are important to me would approve of my recycling.

Kebanyakan orang yang penting bagi saya akan bersetuju amalan kitar semula saya.

My friends expect me to recycle household materials.

Rakan-rakan saya berharap saya mengitar semula bahan rumah.

My family expects me to recycle household materials.

Keluarga saya mengharapkan saya mengitar semula bahan rumah.

\section{Perceived Behavioral Control}

Kawalan Tingkah Laku

I have plenty of opportunities to recycle.

Saya mempunyai banyak peluang untuk mengitar semula.

Recycling is convenient.

Kitar semula adalah mudah.

Recycling is easy.

Kitar semula adalah senang.

I know where to take my household waste for recycling.

Saya tahu di mana hendak membawa sampah isi rumah saya untuk dikitar semula.

I know how to recycle my household waste.

Saya tahu bagaimana mengitar semula sampah isi rumah saya.

I have enough time to sort the materials for recycling.

Saya mempunyai masa yang cukup untuk menyusun bahan untuk dikitar semula.

I have enough space to store the materials for recycling.

Saya mempunyai ruang yang cukup untuk menyimpan bahan untuk dikitar semula.

\section{Moral Norm}

Norma Moral

I feel I should not waste anything if it could be used again.

Saya rasa saya tidak patut membuang apa-apa jika ia dapat digunakan lagi.

It would be wrong of me not to recycle my household waste.

Adalah salah bagi saya untuk tidak mengitar semula sampah rumah saya.

I would feel guilty if I did not recycle my household waste. 
Saya akan berasa bersalah sekiranya saya tidak mengitar semula sampah rumah saya.

Not recycling goes against my principles.

Tidak mengitar semula bertentangan dengan prinsip saya.

Everybody should share the responsibility to recycle household waste.

Semua orang harus mempunyai tanggungjawab untuk mengitar semula sampah isi rumah.

Consequences Awareness

Kesedaran Akibat

Recycling reduces pollution.

Kitar semula mengurangkan pencemaran.

Recycling reduces wasteful use of landfills.

Kitar semula mengurangkan penggunaan tapak pelupusan sampah.

Recycling conserves natural resources.

Kitar semula menjimatkan sumber semula jadi.

Recycling improves environmental quality.

Kitar semula meningkatkan kualiti alam persekitaran.

Recycling saves energy.

Kitar semula menjimatkan tenaga.

Perceived Policy Effectiveness

Keberkesanan Dasar

The waste separation bins provided by the Government are sufficient to facilitate recycling.

Tong pengasingan sampah yang disediakan oleh Kerajaan mencukupi untuk memudahkan kitar semula.

The Government provides clear guidelines on recycling.

Kerajaan memberikan garis panduan yang jelas mengenai kitar semula.

The Government's promotion clearly explains the benefits of recycling.

Promosi kitar semula oleh Kerajaan menerangkan dengan jelas faedah kitar semula.

The Government's policy encourages me to recycle.

Dasar Kerajaan mendorong saya untuk mengitar semula.

The Government's policy facilitates me to recycle.

Dasar Kerajaan memudahkan saya mengitar semula.

Behavioral Intention

Niat Tingkah Laku

I intend to recycle my recyclables in the next 4 weeks.

Saya berhasrat untuk mengitar semula barang kitar semula saya dalam 4 minggu akan datang.

I will recycle my recyclables every time I have it for disposal.

Saya akan mengitar semula barang kitar semula saya setiap kali memilikinya untuk dilupuskan.

I am willing to participate in the recycling scheme in the future.

Saya bersedia untuk menyertai skim kitar semula pada masa akan datang. 